\title{
Knowledge and Practices of Perineal Wound Care among Post Partum Women during COVID-19 Pandemic
}

\author{
Shinta Novelia ${ }^{{ }^{*}}$, Rosmawaty Lubis ${ }^{2}$, Erma Sulistyorini ${ }^{3}$
}

1,2,3Midwifery Department, Universitas Nasional Jakarta, shinta.novelia@civitas.unas.ac.id (Corresponding Author)

\begin{tabular}{|c|c|}
\hline Article Info: & ABSTRACT \\
\hline Submitted: & Perineal wound care is one of the factors to prevent infection during the puerperium. \\
\hline 06-08-2021 & Because the perineal is a difficult area to keep dry and clean. Care and observation \\
\hline Revised: & are needed during the puerperium to ensure that the perineum is healed by taking care \\
\hline 08-11-2021 & of the perineum properly and correctly. During the Covid-19 pandemic, postpartum \\
\hline Accepted: & maternal visits to health facilities were very limited because it was to avoid transmitting \\
\hline $19-12-2021$ & $\begin{array}{l}\text { infectious diseases to postpartum mothers. To determine the knowledge of the post- } \\
\text { partum women about the practice of perineal wounds during the Covid-19 pandemic at } \\
\text { the Banjar Health Centre in } 2021 \text {. This descriptive study used a cross sectional } \\
\text { approach. The sample in this study was } 102 \text { respondents with accidental sampling }\end{array}$ \\
\hline DOI: & technique. Data were analyzed using SPSS with Chi Square, which previously tested \\
\hline https://doi.org/10.53713/nhs.v1i3.49 & $\begin{array}{l}\text { the validity and reliability. The practice of treating perineum wounds in the working area } \\
\text { of the Banjar Health Centre obtained an average score of } 73.5 \text {. Based on the } \\
\text { knowledge obtained an average value of } 89.2 \text {. The results of the Chi Square test } \\
\text { showed that knowledge had a relationship with perineum wound care practices ( } p= \\
0.001) \text {. There is a relationship berween knowledge and perineal wound care practice }\end{array}$ \\
\hline & $\begin{array}{l}\text { among postpartum women. Postpartum women can expand their knowledge about } \\
\text { wound care in the perineum durina the puerperium throuah mass and electronic media }\end{array}$ \\
\hline (c) & and counseling provided by health personnel. \\
\hline
\end{tabular}

This work is licensed under CC BY-SA License.
Keywords: knowledge; perineum wound care practices; post-partum women

\section{INTRODUCTION}

Midwifery problems in the community are complex problems and need to be improved cross-programme handling. These problems include maternal and child mortality. A death that should not have happened and could have been avoided. Every day in 2017, approximately 810 women died from preventable causes related to pregnancy and childbirth (WHO, 2017). Twenty-three percent of deaths to women of reproductive age (15-49 years) in Bali, Indonesia and Menoufia, Egypt were due to maternal causes. In both areas complications of pregnancy and childbirth were a leading cause of death (the first cause in Bali, the second in Menoufia) (Fortney et al., 1988). In both sites, postpartum hemorrhage was the most common cause of maternal death.

The pregnancy rate in Banten Province during the Covid-19 pandemic reached tens thousands. Data from the Banten Province Health Office (Dinas Kesehatan) recorded 84.864 pregnant women in the period January to April 2020. The number of visits by the first pregnant women to health care facilities in January-April 2020 in Pandeglang Regency was 8.239 or fewer than in 2019 in the same period of 8964 people. The puerperium (puerperium) begins after the placenta is born and ends when the uterine organs return to their pre-pregnancy state. The puerperium lasts approximately 6 weeks or 42 days. During the puerperium, maternal death can be caused by puerperal infection (10\%), this can occur due to lack of wound care, bleeding (42\%) due to birth canal tears, retained placenta and uterine atony, eclampsia (13\%) and complications during the puerperium (11\%) (Suyono, 2011).

The success of maternal health efforts during the postpartum period can be measured through indicators of health service coverage for postpartum women (coverage of KF-3). This indicator can be used to assess a country's ability to provide quality health services to postpartum women. That's why care during the puerperium is very necessary because it is a critical period for both mother and baby. Factors that hinder the achievement of postpartum visits 3 (KF 3 ), some of which are the low knowledge of postpartum women and their families about the importance of health education, so that it can affect the low visits of postpartum women to health service facilities. Women who are giving birth for the first time are usually motivated to do postpartum visits because this is a new thing for them. Meanwhile, for 
women who have given birth more than once, they have the assumption that they have previous experience and are used to what usually happens during the postpartum period, so they are lazy to make visits to health services.

Visits during the puerperium are very necessary to detect early complications that occur in postpartum women. One of them is the treatment of wounds to the perineum, injuries to the birth canal can be ensured during delivery, especially for women who are giving birth for the first time. With this injury, it can be a way for bacteria to enter which can lead to infection during the puerperium. The puerperium is a period that is considered important for health workers to always carry out monitoring because monitoring that is not optimal can cause the mother to experience several problems, which can lead to complications during the puerperium such as puerperal sepsis. Post-delivery services during the COVID-19 pandemic are different from the period before the pandemic. Where post-partum services during the pandemic are carried out according to the zones of each region. During the COVID-19 pandemic, postpartum services were carried out with visits by health workers to homes by appointments and by continuing to apply health protocols.

Parturient with stitched perineum after vaginal birth suffer some complications, one of which was infection. Infection is one of the most common causes of maternal death. For this reason, skilled health workers are needed to provide midwifery care for postpartum women during the Covid-19 pandemic. Care during the postpartum period needs attention because about $60 \%$ of maternal mortality occurs during this period (Takemoto et al., 2020). A low knowledge or lack of possibility of infection will be greater due to errors in perineal wound care. Postpartum women' knowledge about poor perineal wound care, such as not washing hands, not washing the perineal wound with soapy water, not drying the genitalia after urinating and defecating, and not washing from front to back will cause infection in the perineum (Gommesen, Nohr, Drue, Qvist \& Rasch, 2019).

By doing good postpartum care we can avoid the possibility of postpartum hemorrhage, and infection. If there is a laceration of the birth canal or an episiotomy scar, it is necessary to treat the wound as well as possible. There are still many women who do not know how to properly treat perineal wounds, because they only change pads once a day, without washing their hands before and after treatment, and without drying with a tissue or small towel so that the perineal surface becomes moist. Thus, this study was aimed to identify the relationship of knowledge and perineal wound care practice among postpartum women.

\section{METHOD}

The design of this research is a survey study with a cross sectional approach. The population in this study was 102 postpartum women in January 2021 in the work area of Banjar Health Centre. The sample used in this was a total population with accidental sampling technique which consisted of 102 postpartum women on January at the work area of Banjar Health Centre. The variables were knowledge related to wound care and wound care practices. A questionnaire regarding knowledge and practice of wound care has been developed by the researcher. It has been tested for validity and reliability (cronbach alpha $=0.732$ ). This study has gained the approval from Universitas Nasional by Letter Number 032/D/SP/FIKES/ // 2021 and Banjar Health Centre by Letter Number 800/684/PKM-BJR/I/2021.

\section{RESULT}

Table 1. The frequency distribution of variables

\begin{tabular}{lcc}
\hline \multicolumn{1}{c}{ Variables } & $(\mathrm{n})$ & $(\%)$ \\
\hline Knowledge & 11 & 10.8 \\
$\quad$ Good & 91 & 89.2 \\
$\quad$ Poor & 27 & \\
\hline $\begin{array}{l}\text { Perineum wound care } \\
\text { Inappropriate }\end{array}$ & 75 & 26.5 \\
$\quad$ Appropriate & 102 & 73.5 \\
\hline \multicolumn{2}{r}{ Total } & 100.0 \\
\hline
\end{tabular}

The results showed that out of 102 postpartum women, 91 (89.2\%) had a good knowledge regarding perineum wound care and 75 (73.5\%) practice perineum wound care appropriately. 
Table 2. The relationship between knowledge and perineum wound care

\begin{tabular}{|c|c|c|c|c|c|c|c|}
\hline \multirow[b]{3}{*}{ Knowledge } & \multicolumn{4}{|c|}{ Perineal Wound Care } & \multirow{2}{*}{\multicolumn{2}{|c|}{ Total }} & \multirow{3}{*}{$p$} \\
\hline & \multicolumn{2}{|c|}{ Inappropriate } & \multicolumn{2}{|c|}{ Appropriate } & & & \\
\hline & $n$ & $\%$ & $\mathrm{n}$ & $\%$ & $\mathrm{n}$ & $\%$ & \\
\hline Poor & 8 & 72.7 & 3 & 27.3 & 11 & 100 & 0.01 \\
\hline Good & 19 & 20.9 & 72 & 79.1 & 91 & 100 & \\
\hline Total & 27 & 26.5 & 75 & 73.5 & 102 & 100 & \\
\hline
\end{tabular}

Based on table 2, it can be concluded that out of 91 respondents who have good knowledge, majority of respondents practice perineum wound care appropriately (79.1\%). Out of 11 respondents who have poor knowledge, majority of them practice perineum wound care in appropriately (72.7\%). From the statistical test obtained $p$-value $(0.01)$ $<(0.05)$, it can be concluded that there was a significant relationship between knowledge and practice of perineum wound care during the covid-19 pandemic at the work area of Banjar Health Centre, Pandeglang Regency.

\section{DISCUSSION}

Notoadmodjo (2010) stated that knowledge is the result of knowing and this occurs after someone has sensed a certain object. Sensing occurs through the five human senses consisting of the senses of sight, smell, taste, touch, and taste. A person's higher level of knowledge will have an impact on a better direction. So that women who have good knowledge will be more objective and open their horizons in making positive decisions or actions. It can be concluded that a good level of knowledge can influence postpartum women in practicing perineum wound care.

The previous study revealed that Majority of women had poor knowledge and practice regarding perennial Care (Muhammad, 2021). But this study did not analyze the relationship between two variables. Another study found a significant relationship between level of vulva hygiene knowledge, food restrictions, behavioral restrictions, and the length of perineal wound healing in postpartum women (Mole, Anggraeni, \& Sumeru, 2019). It is recommended that health care providers increase postpartum mothers' knowledge about perineal wound healing and cultural beliefs during postpartum period which may inhibit wound healing. In addition, a study conducted in Banjarmasin found that here was a correlation between maternal knowledge and Perineum wound healing and correlation between postpartum attitude toward perineal wound healing (Rahayu, Saputri \& Rahmadaniah, 2017). A study conducted in egypt found that puerperal women who had received perineal self-care instructions experienced lower episiotomy pain and faster episiotomy healing than those who hadn't received instructions (Zaki, L-Habashy, Aziz, \& Elkhatib, 2019). It was recommended that health professionals must be properly trained and updated regarding guidelines and its harmful consequences to women's physical and psychic health.

Women who were taught postpartum perineal wound care practiced it and this resulted in better wound healing progress, therefore, it is recommended that postpartum self-perineal wound care be introduced to antenatal mother, guidelines on perineal wound care be made available in delivery centers, Midwives should encourage parturient to practice care while on admission and encourage mothers to practice care when discharged home (Ari, Sotunsa, Leslie, Inuwa Ari \& Kumzhi, 2019). There is a need to explore other variable which might contribute to perrineal wound care such as nutrition Frilasari, Saudah, Prameswari, Azizah, \& Suhita, 2020), perineal wound education program for midwife (Diaz \& Steen, 2017), attitude (Rahayu, Saputri, \& Rahmadaniah, 2017) etc.

\section{CONCLUSION}

The results showed the relationship between the level of knowledge and practice of perineal wound care at the work area of Banjar Health Centre. It is hoped that postpartum women can increase their knowledge about wound care especially perineum wound care through counseling and information media such as print media and electronic media. As well as being able to attend classes for pregnant women while still adhering to health protocols. The midwives need to put attention to provide health promotion regarding perineum wound healing for post-partum women before discharge. 


\section{REFERENCES}

Ari, E. S., Sotunsa, J. O., Leslie, T. A., Inuwa Ari, S., \& Kumzhi, P. R. (2019). Impact of an educational intervention on postpartum perineal wound care among antenatal mothers in Jos: A quasi-experimental study. Clinical Practice, 16(6), 1409-1422.

Diaz, M. P., \& Steen, M. (2017). Innovation in digital learning: Perineal wound care education. Women and Birth, 30, 29.

Gommesen, D., Nohr, E. A., Drue, H. C., Qvist, N., \& Rasch, V. (2019). Obstetric perineal tears: risk factors, wound infection and dehiscence: a prospective cohort study. Archives of gynecology and obstetrics, 300(1), 67-77.

Frilasari, H., Saudah, N., Prameswari, V. E., Azizah, Y. N., \& Suhita, B. M. (2020). Nutritional Pattern And Healing Of Perineum Wound On Postpartum Period. Journal Of Nursing Practice, 3(2), 172-180.

Fortney, J. A., Susanti, I., Gadalla, S., Saleh, S., Feldblum, P. J., \& Potts, M. (1988). Maternal mortality in Indonesia and Egypt. International Journal of Gynecology \& Obstetrics, 26(1), 21-32.

Louis Shanthi, R. (2012). Effectiveness of Self Perineal Care Practices on Episiotomy Wound among the Primi Postnatal Mothers at Selected Maternity Hospital, Trichy (Doctoral dissertation, Dr. G. Sakunthala College of Nursing, Trichy).

Mole, M., Anggraeni, M., \& Sumeru, A. (2019). The relationship between level of knowledge about vulva hygiene and the restrictions during childbirth with the perineal wound healing among postpartum mothers. Annals of Tropical Medicine and Public Health, 22, 356-362.

Muhammad, M. A. (2021). Knowledge and Practices Regarding Episiotomy and Perineal Care among Primiparous Women. Indian Journal of Forensic Medicine \& Toxicology, 15(3).

Notoadmojdo, S. (2010). Pendidikan dan Perilaku Kesehatan. Jakarta: Rineka Cipta

Notoadmodjo, S. (2014). Perilaku Kesehatan dan IImu Perilaku. Jakarta: Rineka Cipta

Rahayu, Y. P., Saputri, R., \& Rahmadaniah, N. (2017). Analysis Of Knowledge And Attitudes On Perineal Wound Healing In Postpartum Mother In The Area Of Pekauman Public Health Center In South Banjarmasin. Advances in Health Science Research, 6, 1-11.

Takemoto, M. L., Menezes, M. O., Andreucci, C. B., Knobel, R., Sousa, L. A., Katz, L., .. \& Amorim, M. M. (2020). Maternal mortality and COVID-19. The Journal of Maternal-Fetal \& Neonatal Medicine, 1-7.

WHO. (2017). Maternal Mortality. Retrieved from https://www.who.int/news-room/fact-sheets/detail/maternal-mortality.

Zaki, N. H., L-Habashy, M. M. E., Aziz, N. I. A., \& Elkhatib, H. M. Effect of Perineal Self Care instructions on Episiotomy Pain and Healing among postpartum Women. 